\title{
Monobloc Total Thyroidectomy Using Sealing Devices: Preliminary Results and Comparative Analysis
}

\section{Călin Molnar', Marian Botoncea', Vlad Olimpiu Butiurca', Cosmin Lucian Nicolescu', Claudiu Varlam Molnar², Bianca Liana Grigorescu ${ }^{3}$}

${ }^{1}$ Surgical Clinic No.1, Emergency Clinical County Hospital, Târgu Mureș Romania George Emil Palade University of Medicine, Pharmacy, Science and Technology of Târgu Mureș, Romania ${ }^{2}$ Obstetrics and Gynecology Clinic, Emergency Clinical County Hospital, Târgu Mureș, Romania George Emil Palade University of Medicine, Pharmacy, Science and Technology of Târgu Mureș, Romania ${ }^{3}$ Anesthesiology and Intensive Care Clinic, Emergency Clinical County Hospital, Târgu Mureș, Romania George Emil Palade University of Medicine, Pharmacy, Science and Technology of Târgu Mureș, Romania

Corresponding author: Marian Botoncea, MD, PhD student Surgical Clinic No.1

Emergency Clinical County Hospital 38 Gheorghe Marinescu St, 540139 Târgu Mureș, Romania

E-mail:botonceam@gmail.com
Received: 25.08 .2019 Accepted: 30.09 .2019

\section{Rezumat}

Tiroidectomia totală monobloc cu instrumente de hemostază-sigilare: rezultate preliminare și analiza comparativă

Background: Dorința unei hemostaze perfecte a determinat industria echipamentelor medicale să producă instrumente „ideale” necesare unei tiroidectomii sigure. Astfel, instrumentele de hemostază-sigilare, cum ar fi LigaSure ${ }^{\mathrm{TM}}$ Small Jaw, Thunderbeat $^{\mathrm{TM}}$ Open Fine Jaw şi Harmonic ${ }^{\mathrm{TM}}$ Focus au fost concepute pentru chirurgia tiroidiană.

Scop: Scopul acestui studiu este de a prezenta rezultatele inițiale ale utilizării acestor trei instrumente chirurgicale pentru efectuarea tiroidectomiei monobloc.

Materiale and Metodă: Am efectuat un studiu prospectiv între ianuarie 2014 şi iulie 2019, în care am inclus toți pacienții operați de acelaşi chirurg folosind aceste 3 dispozitive de sigilare. Tiroidectomiile au fost efectuate folosind LigaSure ${ }^{\mathrm{TM}}$ Small Jaw (grupul 1), Thunderbeat ${ }^{\mathrm{TM}}$ Open Fine Jaw (grupul 2) şi Harmonic ${ }^{\mathrm{TM}}$ Focus (grupul 3). Grupurile au fost comparate statistic din punct de vedere al duratei intervenției chirurgicale şi a spitalizării, complicațiilor postoperatorii timpurii, precum şi alterarea vocii sau aparitia insuficienței respiratorii acute.

Rezultate: $\mathrm{Nu}$ s-au observat diferente semnificative între grupuri în ceea ce priveşte datele demografice a pacienților, diagnosticul patologic preoperator, complicatiile postoperatorii precoce şi durata spitalizării. Timpul operator a fost mai scurt în grupul 1. Concluzii: Noile instrumente chirurgicale au proprietăți benefice, 
inclusiv scurtarea timpului operator, menținerea unui câmp de operare curat şi minimizarea fumului degajat în timpul intervenției chirurgicale.

Cuvinte cheie: Tiroidectomie, LigaSure ${ }^{\mathrm{TM}}$ Small Jaw, Thunderbeat ${ }^{\mathrm{TM}}$ Open Fine Jaw, Harmonic ${ }^{\mathrm{TM}}$ Focus

\begin{abstract}
Background: The desire for perfect haemostasis has led the medical equipment industry to produce "ideal" instruments for safe thyroidectomy. Thus, haemostasis and sealing instruments such as the LigaSure ${ }^{\mathrm{TM}}$ Small Jaw, Thunderbeat ${ }^{\mathrm{TM}}$ Open Fine Jaw and Harmonic ${ }^{\mathrm{TM}}$ Focus have been indicated for thyroid surgery.

Aim: The purpose of this study is to present the initial results of using these three surgical instruments for performing monobloc thyroidectomy.

Material and Methods: We performed a prospective study between January 2014 and July 2019 in which we included all the patients operated by same surgeon using those 3 sealing devices. Thyroidectomies were performed using LigaSure ${ }^{\mathrm{TM}}$ Small Jaw (group 1), the Thunderbeat ${ }^{\mathrm{TM}}$ Open Fine Jaw (group 2) and Harmonic ${ }^{\mathrm{TM}}$ Focus (group 3). The groups were statistically compared in term of duration of surgery and hospitalisation, early postoperative complications as well as voice alteration or acute respiratory failure.

Results: No significant differences were observed among groups in terms of patient demographics, pathological diagnoses, postoperative complications, length of hospitalization, and clinical outcomes. Operating time was shorter in group 1.

Conclusions: New surgical instruments have beneficial properties, including shortening the operative time, maintaining a clean operating field, and minimising smoke released during the operation.
\end{abstract}

Key words: Thyroidectomy, LigaSure ${ }^{\mathrm{TM}}$ Small Jaw, Thunderbeat ${ }^{\mathrm{TM}}$ Open Fine Jaw, Harmonic ${ }^{\mathrm{TM}}$ Focus

\section{Introduction}

Total thyroidectomy, as it is known today, began in the late 19th century, when Theodor Kocher underwent a meticulous thyroidectomy, reducing the mortality of this surgery to less than $1 \%(1)$.

Although the technique of thyroidectomy has changed very little over the years, different techniques for haemostasis have been developed in addition to conventional methods (2).

The desire for perfect haemostasis has led the medical equipment industry to produce "ideal" instruments for safe thyroidectomy. Thus, haemostasisand sealing instruments such as the LigaSure ${ }^{\mathrm{TM}}$ Small Jaw, Thunderbeat $^{\text {TM }}$ Open Fine Jaw and Harmonic $^{\mathrm{TM}}$ Focus have been indicated for thyroid surgery $(3,4,5)$.

The purpose of this study is to present the initial results of using these three surgical instruments for performing monobloc thyroidectomy, also reported to the literature.

\section{Material and Methods}

We performed a prospective study in the General Surgery Clinic 1 of the Emergency Clinical County Hospital of Târgu Mureş, between 1 January 2014 and July 2019. A total of 45 successive patients were divided 
into groups of 15 , in which thyroidectomy was performed using different sealing devices. The LigaSure $^{\mathrm{TM}}$ Small Jaw was used for group 1, the Thunderbeat ${ }^{\mathrm{TM}}$ Open Fine Jaw was used for group 2 and the Harmonic ${ }^{\mathrm{TM}}$ Focus was used for group 3. All patients underwent a complete evaluation preoperatively, including biochemical parameters, fine needle biopsy puncture and otology examination, as well as gynaecological evaluation for women. A postoperative examination was performed by the otologist only if there were phonation disorders or signs of respiratory failure. Patients with a known history of neck surgery and/or radiation therapy or dysphonia were excluded from the study,as was one patient undergoing treatment with TNF-alpha inhibitor (adalimumab) who had elevated eosinophils (6). The groups were statistically compared in term of duration of surgery and hospitalisation, early postoperative complications as well as voice alteration or acute respiratory failure.

All patients were informed about the characteristics of these devices and of the possible implicit complications.

The study was performed in accordance with the Declaration of Helsinki, Good Clinical Practice, and applicable regulatory requirements. Written consent was obtained from all patients before the initiation of surgery.

\section{Surgical Technique}

The surgery was performed by a single surgeon with experience in endocrine surgery, following the same operative steps, with the only difference being the sealing-haemostasis device used. The surgery begins with a Kocher-type arched incision in the anterior cervical region of $3-5 \mathrm{~cm}$, approximately $1 \mathrm{~cm}$ below the cricothyroid cartilage. The subcutaneous cell tissue and platysma muscle are sectioned and then the two flaps are prepared. The upper flap is suspended using a thread to the chin, then the median raphe of the muscles is divided and the thyroid lodge is opened.

The monobloc thyroidectomy is performed in a motion like pulling a toy brick, from left to right as in browsing the tabs of a book, by sealing the inferior thyroid pedicle (Fig. 1).

The surgical intervention continues with the sealing of the middle and superior pedicles. The dissection proceeds from left to right, cutting the posterior ligaments of Berry (Fig. 2), detaching the isthmus and entering the right thyroid lodge (Fig. 3).

Following the same intraoperative steps, the right lobe is dissected, and the last step is sealing the superior thyroid pedicle of the right lobe (Fig. 4). In this way, the monobloc thyroid specimen is obtained for histopathological examination (Fig. 5).

The thyroid lodge is drained, followed by suture of the median raphe, resorbable suture of the subcutis and intradermal skin suture. Monopolar cautery is used as an auxiliary method of haemostasis in all patients.

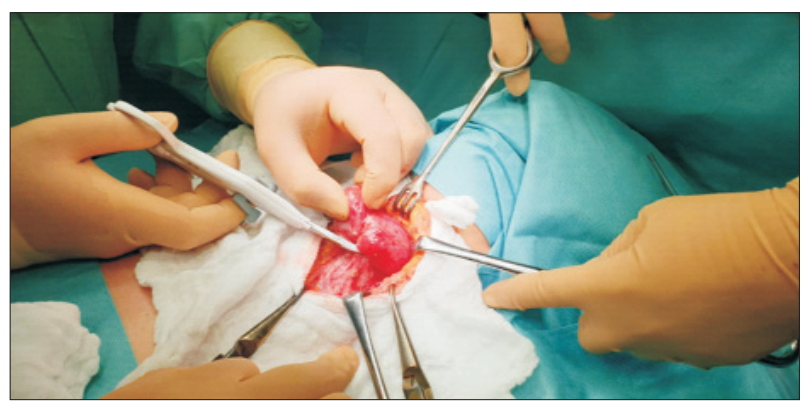

Figure 1. Sealing the inferior pedicle of the left lobe

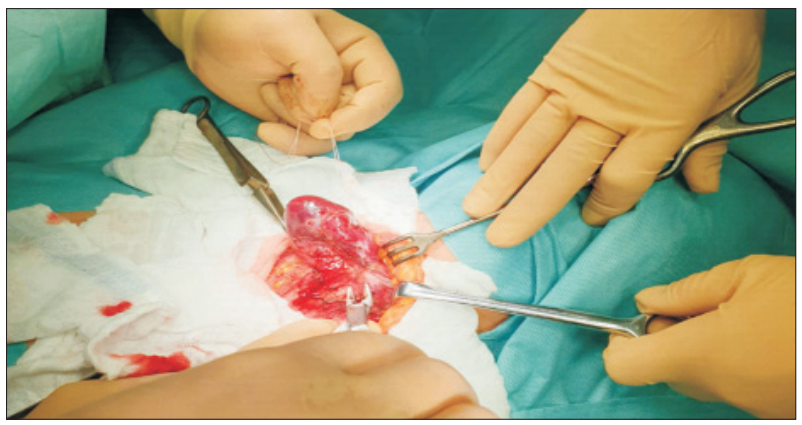

Figure 2. Sectioning of the suspensory ligaments and further dissection towards the upper pedicle A traction thread is used to facilitate mobilisation of the thyroid lobe. 


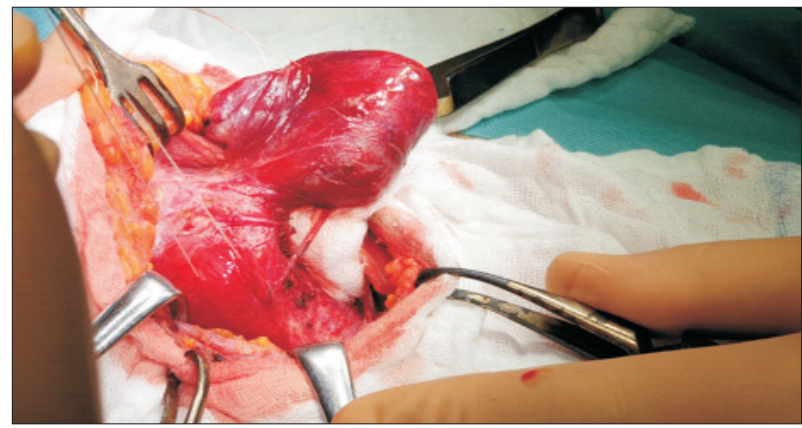

Figure 3. Entering the right thyroid lodge

\section{Results}

Monobloc thyroidectomy was performed in all patients,with no reported deaths or wound infections.

Quantitative data were expressed as mean \pm standard deviation (SD), while qualitative data (sex and biopsy puncture result) were expressed as percentages or numbers.

The demographic and clinical data of the three patient groups were similar, and are represented in Table 1.

The operative time was measured from incision to skin suture, without significant statistical differences. The results are represented in Table 2.

The hospitalisation periods were similar.

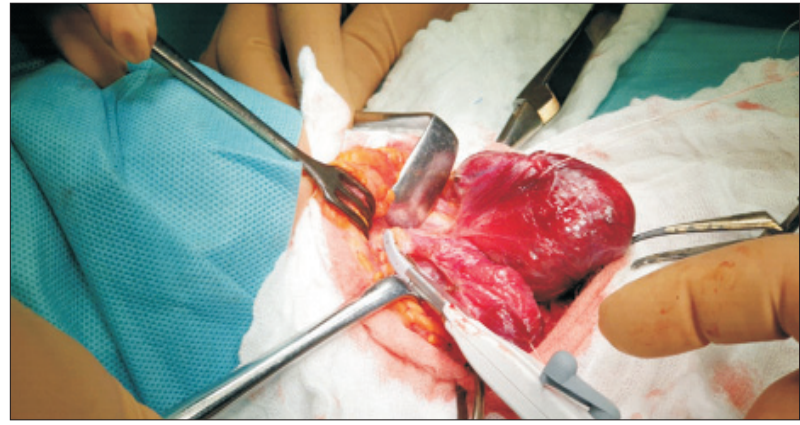

Figure 4. Sealing the upper thyroid pedicle of the right lobe

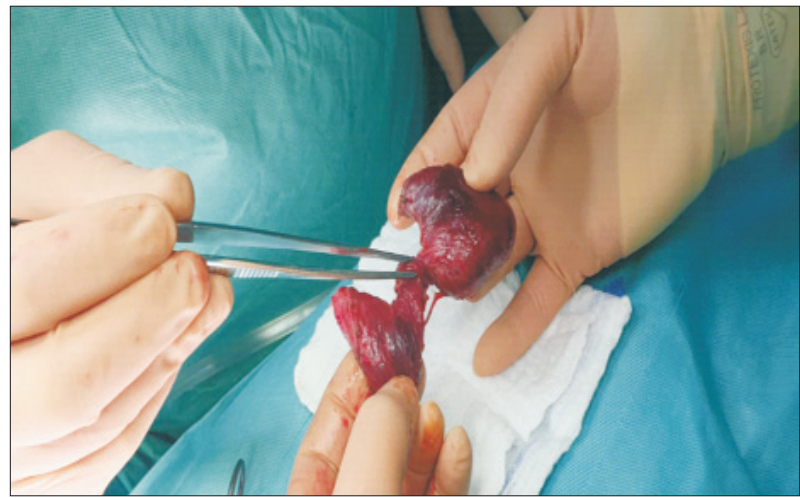

Figure 5. Thyroid monobloc specimen

All patients had a minimum of two days, and the maximum for each group was six or seven days (Table 3). Applying the ANOVA test to

Table 1. Clinical and demographic data

\begin{tabular}{|c|c|c|c|}
\hline & $\begin{array}{l}\text { Group } 1 \\
\text { LigaSure }^{\mathrm{TM}}\end{array}$ & $\begin{array}{c}\text { Group } 2 \\
\text { Thunderbeat }^{\mathrm{TM}}\end{array}$ & $\begin{array}{c}\text { Group } 3 \\
\text { Harmonic }^{\mathrm{TM}}\end{array}$ \\
\hline Median age & $58.26 \pm 8.18$ & $61.66 \pm 9,65$ & $64.6 \pm 9.84$ \\
\hline Women/Men & $14 / 1$ & $13 / 2$ & $12 / 2$ \\
\hline \multicolumn{4}{|c|}{ Preoperative histopathological diagnosis } \\
\hline Nodular goitre & 11 & 11 & 10 \\
\hline Malignancy & 2 & 3 & 4 \\
\hline Basedow-Graves disease & 2 & 1 & 1 \\
\hline
\end{tabular}

Table 2. Operative times in minutes

\begin{tabular}{|c|c|c|c|}
\hline Operative time & $\begin{array}{c}\text { Group } 1 \\
\text { LigaSure }^{\mathrm{TM}}\end{array}$ & $\begin{array}{c}\text { Group } 2 \\
\text { Thunderbeat }^{\mathrm{TM}}\end{array}$ & $\begin{array}{c}\text { Group } 3 \\
\text { Harmonic }^{\mathrm{TM}}\end{array}$ \\
\hline Mean & 67.66 & 79.13 & 76.66 \\
\hline Minimum & 40 & 55 & 45 \\
\hline Maximum & 110 & 100 & 110 \\
\hline SD & 22.5 & 13.38 & 18.58 \\
\hline
\end{tabular}


Table 3. Hospitalisation period

\begin{tabular}{lccc}
\hline Hospitalisation & $\begin{array}{c}\text { Group 1 } \\
\text { LigaSure }^{\mathrm{TM}}\end{array}$ & $\begin{array}{c}\text { Group 2 } \\
\text { Thunderbeat }^{\mathrm{TM}}\end{array}$ & $\begin{array}{c}\text { Group 3 }^{\text {Harmonic }} \\
\text { Harm }^{\mathrm{TM}}\end{array}$ \\
\hline Mean \pm standard deviation & $3.06 \pm 1.53$ & $4 \pm 1.41$ & $3.6 \pm 1.24$ \\
\hline Minimum & 2 & 2 & 2 \\
\hline Maximum & 7 & 7 & 6 \\
\hline
\end{tabular}

compare the means of the three groups showed no statistically significant difference $(p=0.1998)$.

There were no manifestations of permanent hypocalcaemia in the studied groups. Transient disturbances of calcium balance were countered by calcium administration intravenously and then orally.

In the three groups of patients, some phonation complications and some postoperative haematoma occurred, as shown in Table 4.

\section{Discussion}

Total monobloc thyroidectomy can be performed safely with a low complication rate. This requires a good command of the surgical technique, knowing the local anatomy and ensuring rigorous haemostasis.

The use of the LigaSure ${ }^{\mathrm{TM}}$ Small Jaw device in complete total thyroidectomy has been shown to be safe and effective in reducing operative time, intraoperative blood loss and postoperative fluid drainage. This sealing device yields better results regarding the function of the recurrent laryngeal nerves and the condition of the parathyroid glands $(7,8)$

The Thunderbeat ${ }^{\mathrm{TM}}$ Open Fine Jaw is the only device currently available in the world capable of simultaneously providing frictional thermal energy through ultrasound and bipolar power generation (9). Years of study on this device have shown that this combination of bipolar and ultrasonic energy is more beneficial in surgery compared to devices using only ultrasound (Harmonic Focus ${ }^{\mathrm{TM}}$ ) or only bipolar energy (LigaSure ${ }^{\mathrm{TM}}$ Small Jaw). The efficiency and versatility offered by this device are very useful and represent an important step towards achieving perfection in modern surgery (10).

Operative time is greatly influenced by the surgeon's experience, as shown by Patoir et al (11). The mean operating time in this study was not statistically significantly different between groups, or from the average time of 86 minutes reported in the literature. However, the group using the LigaSure ${ }^{\mathrm{TM}}$ Small Jaw had a mean operating time 11.47 minutes shorter than the Thunderbeat $^{\mathrm{TM}}$ group, and 9 minutes shorter than the Harmonic ${ }^{\mathrm{TM}}$ group.

The average length of hospitalisation was similar for all groups. The mean value was higher compared to data in the literature, which suggests that the average hospitalisation period is two days (12). Recent studies suggest that thyroidectomy should be performed under day conditions, dependent on the surgeon, patient and hospital (13).

The use of sealing devices was effective in all groups in the present study. All vascular

Table 4. Number of patients affected by early postoperative complications

\begin{tabular}{lccc}
\hline Complication & $\begin{array}{c}\text { Group 1 } \\
\text { LigaSure }^{\mathrm{TM}}\end{array}$ & $\begin{array}{c}\text { Group 2 } \\
\text { Thunderbeat }^{\mathrm{TM}}\end{array}$ & $\begin{array}{c}\text { Group 3 } \\
\text { Harmonic }^{\mathrm{TM}}\end{array}$ \\
\hline Dysphonia & 3 & 3 & 2 \\
\hline Acute respiratory failure & 0 & 1 & 0 \\
\hline Haematoma & 2 & 1 & 2 \\
\hline
\end{tabular}


structures were successfully sealed without the need for other haemostasis adjuvants during surgery.

Regarding complications, a patient belonging to group 2 , whose postoperative evaluation was apparently favourable, unfortunately presented on the second day with acute respiratory failure that did not recover conservatively. The patient was transferred to the otology department, where a tracheostomy was performed.

The authors' overall view is that the LigaSure $^{\mathrm{TM}}$ Small Jaw device has an advantage due to its ergonomics and easy handling compared to the other devices.

\section{Conclusions}

Monobloc total thyroidectomy is a feasible therapeutic method for the surgical treatment of thyroid disorders.

New surgical instruments have beneficialproperties, including shortening the operative time, maintaining a clean operating field, and minimising smoke released during the operation.

The ergonomics of the sealing instruments used in this study, as well as the fact that they need not be changed during surgery, bring added bonuses for surgical comfort.

\section{Conflict of Interests}

The authors declare noconflicts of interests.

\section{References}

1. Molnar C, Butiurca VO, Molnar VC, Botoncea M. Thyroidectomy without Ligatures in Differentiated Thyroid Cancer, Cancer Survivorship, DilAfroze, Intech0pen, 2018, DOI: 10.5772/intechopen.79730. Available from: https://www.intechopen.com/books /cancer-survivorship/thyroidectomy-without-ligatures-in-differentiated-thyroid-cancer

2. Revelli L, Damiani G, Bianchi CBNA, Vanella S, Ricciardi W, Raffaelli $M$, et al. Complications in thyroid surgery. Harmonic Scalpel, Harmonic Focus versus Conventional Hemostasis: A meta-analysis. Int. J. Surg. 2016;28(I): S22-S32

3. https://www.medtronic.com/covidien/en-us/products/vesselsealing/ligasure-small-jaw.html

4. https://www.olympus-europa.com/medical/en/Products-andSolutions/Products/Product/THUNDERBEAT-Open-Fine-Jaw.html

5. https://www.ethicon.com/na/epc/code/hargf?lang=en-default

6. Chiriac A, Brzezinski P, Stolnicu S, Podoleanu C, Moldovan C, Molnar Cet al. Eosinophilia - A rare possible adverse reaction during anti-tumor necrosis factor-alphatherapy for psoriasis. J. Dermatol. Treat. 2016;27(2): 110-113

7. Al Juraibi W, Ahmed M R, Saber A. Use of Ligasure Sealing Versus Conventional Suture - Ligation in Total Thyroidectomy. Journal of Surgery. 2016; 4(3-1):34-38

8. Molnar C, Voidăzan S, Rad C, Neagoe V, Roșca C, Barna L et al. Total Thyroidectomy with LigaSure Small Jaw versus Conventional Thyroidectomy - a Clinical Study. Chirurgia (Bucur). 2014;109(5): 608-612.

9. Obonna G C, Mishra RK. Differences between Thunderbeat, LigaSure and Harmonic Scalpel Energy System in Minimally Invasive Surgery. World Journal of Laparoscopic Surgery with DVD. 2014; 7: 41-44.

10. Seehofer D, Mogl M, Boas-Knoop S, Unger J, Schirmeier A, Chopra $S$, et al. Safety and efficacy of new integrated bipolar and ultrasonic scissors compared to conventional laparoscopic 5-mm sealing and cutting instruments. Surg Endosc. 2012; 26(9): 2541-2549.

11. Patoir A, Payet C, Peix JL, Colin C, Pascal L, Kraimps JL, et al. Determinants of operative time in thyroid surgery: A prospective multicenter study of 3454 thyroidectomies. PLoS One. 2017;12(7): e0181424.

12. Dedivitis RA, Pfuetzenreiter EG Jr, Castro MA, Denardin OV. Analysis of safety of short-stay thyroid surgery. Acta Otorhinolaryngol Ital. 2009;29(6):326-330.

13. Butler D, Oltmann S. Is Outpatient Thyroid Surgery for Everyone?. Clin Med Insights Ear Nose Throat. 2017;10:1179550617724428. 